\title{
Effect of geographic range discontinuity on species differentiation-East-Mediterranean Abies cilicica: a case study
}

\author{
Katarzyna Sękiewicz • Monika Dering • Maciej Sękiewicz • \\ Krystyna Boratyńska • Grzegorz Iszkuło • Monika Litkowiec • \\ Tolga Ok • Magda Bou Dagher-Kharrat • Adam Boratyński
}

Received: 3 June 2014 / Revised: 17 October 2014 / Accepted: 27 October 2014 /Published online: 22 November 2014

(C) The Author(s) 2014. This article is published with open access at Springerlink.com

\begin{abstract}
In the present study, a genetic analysis of nuclear microsatellites was conducted in Abies cilicica populations growing in West Taurus, East Taurus, and Lebanon mountains to obtain evidence for significant genetic differentiation. Despite range fragmentation, all examined populations tended to maintain a relatively high level of genetic diversity $\left(H_{E}=\right.$ $0.724)$ and showed moderate genetic differentiation $\left(F_{S T}=\right.$ $0.134)$ that is frequently noted in Mediterranean tree species. However, significant inbreeding, bottleneck effect, and low effective population sizes were detected, that may negatively affect species genetic resources. Bayesian clustering revealed three distinct groups, "West Taurus", "East Taurus," and "Lebanon", which reflect geographic structure of the species natural range. Minor genetic admixture between Lebanese and East Taurus populations of A. cilicica was found, but no
\end{abstract}

Communicated by Z. Kaya

Electronic supplementary material The online version of this article (doi:10.1007/s11295-014-0810-5) contains supplementary material, which is available to authorized users.

K. Sękiewicz $(\bowtie) \cdot M$. Dering $\cdot$ M. Sękiewicz $\cdot$ K. Boratyńska

G. Iszkuło $\cdot$ M. Litkowiec $\cdot$ A. Boratyński

Institute of Dendrology, Polish Academy of Sciences, Parkowa 5, 62-035 Kórnik, Poland

e-mail: kasia.klajbor@vp.pl

G. Iszkuło

Faculty of Biological Sciences, University of Zielona Góra, Prof. Z. Szafrana 1, 65-516 Zielona Góra, Poland

T. Ok

Department of Forest Botany, Faculty of Forestry, Kahramanmaras

Sutcu Imam University, 46100 Kahramanmaras, Turkey

M. B. Dagher-Kharrat

Laboratoire 'Caractérisation Génomique des Plantes', Faculté des

Sciences, Université Saint-Joseph, Campus Sciences et

Technologies, Mar Roukos, Mkalles, BP: 1514, Riad el Solh,

Beirut 1107 2050, Lebanon genetic admixture between Lebanese populations and West Taurus. We argue that significant genetic differentiation discovered among areas of species occurrence is probably due to the effect of long-lasting genetic isolation that started in that region along with the Pleistocene climatic alternation and was further enhanced with human-induced deforestations.

Keywords Biogeography · Cilician fir · Mediterranean region $\cdot \mathrm{nSSR}$ markers $\cdot$ Plant diversity

\section{Introduction}

What mechanisms are responsible for the genetic divergence leading to speciation is one of the major questions in evolutionary biology (Schluter 2001; Aguilée et al. 2013; Hopkins 2013). Natural selection driving local adaptations, genetic drift, and mutations are factors that increase genetic differentiation, while gene flow hinders it (Wright 1931; Slatkin 1995). The influence of natural selection and genetic drift on the pattern of differentiation largely depends on the rate of gene transfer between populations mediated by pollen and seed dispersal (Grivet et al. 2009). In wind-pollinated conifers, pollen-mediated gene flow is the main factor acting against genetic differentiation due to the large potential for effective long-distance dispersal (Robledo-Arnuncio 2011). However, range fragmentation may prevent or restrict gene flow between populations and thus support among-population differentiation (Slatkin 1987; Young et al. 1996). Hence, fragmentation resulting in genetic isolation may promote genetic divergence leading to vicariance and constitutes the basic model of speciation, i.e., the allopatric speciation (Mayr 1964; Abbott et al. 2008; Comes et al. 2008).

Abies alba Mill. is the only species from the European representatives of the genus Abies that has a wide, almost continuous range of distribution (Muller et al. 2007). In 
contrast, the current distribution of the majority of the fir species growing in the Mediterranean is highly fragmented (Jalas and Suominen 1988; Schütt 1991). The fragmented pattern of distribution, which is largely the result of the geologic and climatic history of the Mediterranean region where firs have evolved, has fostered differentiation and local adaptations which have led to the emergence of many species, subspecies, and varieties in the genus Abies (Linares 2011). The genetic integrity of a species relies on the genetic connectivity of spatially arranged populations via gene flow. Mediterranean firs, characterized by disjunctive distributions and rather limited pollen dispersal capacity (Poska and Pidek 2009; Geburek et al. 2012), are an excellent evolutionary model for investigating the role of range fragmentation in population divergence.

Cilician fir, Abies cilicica (Antoine and Kotschy) Carrière is a 30-35-m-high tree and can be up to $2 \mathrm{~m}$ in diameter at breast height (Coode and Cullen 1965). It grows in the EastMediterranean region, in the Taurus mountains and Amanus in Turkey, the Jbel Ansariye in Syria, and Jabal Ammoua and Ehden in Lebanon (Browicz and Zieliński 1984; Akkemïk 2000; Kaya and Raynal 2001). In Turkey, it is distributed at elevations between 1,150 and 2,000 $\mathrm{m}$ on the north- and 1,450 and $1,550 \mathrm{~m}$ on the south-facing slopes of the Taurus, optimally at 1,200-1,800 m (Kaya and Raynal 2001). The species forms pure or mixed stands with Pinus nigra J.F. Arnold subsp. pallasiana (Lamb.) Holmboe and Cedrus libani A. Rich. (Kaya and Raynal 2001; Kavgaci et al. 2010). Additionally, Juniperus excelsa M. Bieb., Juniperus foetidissima Willd., and Juniperus drupacea Labill. are components of fir forests that are frequently replaced by juniper communities (Kavgaci et al. 2010). A. cilicica is at risk in its lower elevation localities due to arid conditions (Aussenac 2002; Gardner and Knees 2013) and is a near-threatened species in Lebanon (Talhouk et al. 2003) where fir forests reach their southernmost distribution.

The current geographic distribution of A. cilicica is disjunctive, divided into several dozen areas isolated from each other (Browicz and Zieliński 1984; Kaya and Raynal 2001), while the ancestral taxa may have had a more continuous distribution (Linares 2011). The range fragmentation of this species was strong during cool periods of the Pleistocene because of the profound aridity of the climate during that period (Leroy and Arpe 2007). Based on an extensive pollen record dataset, the Holocene biogeography of Abies indicates that it was more abundant than in the present (Collins et al. 2012). However, modern range fragmentation has become prominent due to the development of an increasingly arid climate and, most recently, due to human-generated deforestation (Roberts et al. 2001). The spatial isolation between the West (Isaurian) Taurus and East Taurus populations is assumed to be a major reason for the differentiation of A. cilicica into two morphologically distinct lineages, an eastern lineage (A. cilicica subsp. cilicica), known also from Syria and Lebanon, and a western lineage (A. cilicica subsp. isaurica Coode and Cullen) with either pubescent or glabrous young shoots, respectively (Coode and Cullen 1965; Farjon 2010).

Considering the current disjunctive distribution of the species, we assumed that fragmentation of the Cilician fir range that has started in Pleistocene in results of climatic alternation was the evolutionary impulse driving within-species differentiation. Using genetic analyses, we investigated whether or not substantial genetic differentiation exists between the A. cilicica populations located in remote and currently isolated parts of the species natural range. Particularly, we wondered if the genetic differentiation of this Mediterranean tree species refers to general patterns of differentiation reported in this region. Since mountain ranges are one of the major factors in establishing biogeographic patterns, we also wanted to characterize the genetic relationships between populations of A. cilicica growing in the different and geographically isolated mountain ranges, i.e., West Taurus, East Taurus, and the Lebanon mountains predicting significant genetic differentiations to be detected. In addition, we wanted to explore the intra-species genetic variability in context of two subspecies that are recognized within A. cilicica based on their morphological distinctiveness.

\section{Materials and methods}

\section{Plant material}

Material for this study was collected from seven natural populations of A. cilicica (Fig. 1 and Table 1). Four of them were from the East Taurus mountains in Turkey and Lebanon mountains and, according to taxonomic classification based on morphology, are representative of A. cilicica subsp. cilicica (Farjon 2010). Three populations sampled in West Taurus are representative of $A$. cilicica subsp. isaurica. Thirty randomly dispersed adult individuals separated by distances $>50 \mathrm{~m}$ were sampled from each natural population with the exception of the LB_2 population where only 12 individuals could be sampled. A total of 192 needle samples from Cilician fir was collected and successfully analyzed in this study.

DNA extraction, SSR amplification, and statistical analysis

Total DNA was extracted from all samples using ca. $50 \mathrm{mg}$ of dry needles according to Dumolin et al. (1995). Eleven nuclear microsatellite markers (nSSR), developed by Cremer et al. (2006) for other Abies species, were tested for uniform response and peak quality in A. cilicica prior to being used for the genetic analysis. 
Fig. 1 Distribution of $A$. cilicica s.l. and population genetic structure according to GENELAND (populations acronyms as in Table 1)

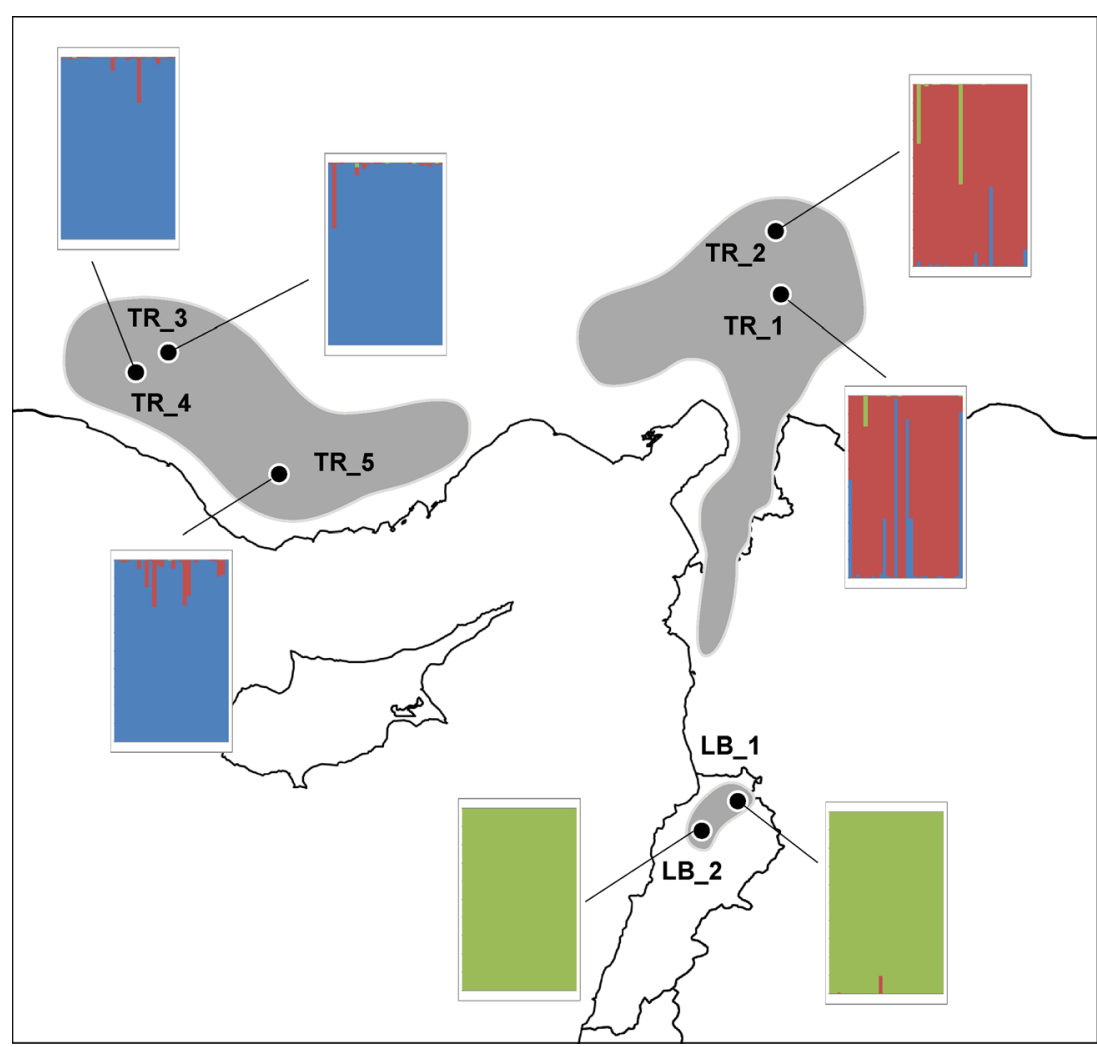

Polymerase chain reaction (PCR) amplification was performed in a single multiplex reaction using a Multiplex PCR Kit (Qiagen, Hilden, Germany), according to the manufacturer's instructions. Amplification was conducted in a thermal cycler, using the following PCR protocol: initial denaturation step at $95{ }^{\circ} \mathrm{C} / 15 \mathrm{~min}$., followed by 35 cycles of denaturation at $94{ }^{\circ} \mathrm{C} / 30 \mathrm{~s}$, annealing at $57{ }^{\circ} \mathrm{C} / 90 \mathrm{~s}$, extension at $72{ }^{\circ} \mathrm{C} / 90 \mathrm{~s}$, and final extension step at $72{ }^{\circ} \mathrm{C} / 10 \mathrm{~min}$. Fluorescently labelled PCR products were separated on a 3130 Genetic Analyser (Applied Biosystems) with the internal size standard GeneScan-500 LIZ (Applied Biosystems). Genotypes were scored using GeneMapper vs. 4.0 (Applied Biosystems).

Genetic diversity parameters, including average number of alleles $(A)$, observed heterozygosity $\left(H_{O}\right)$, expected heterozygosity $\left(H_{E}\right)$, and frequency of the null alleles $\left(N_{0}\right)$ were estimated using INEst v.1.0 (Chybicki and Burczyk 2009). Allelic richness $\left(A_{R}\right)$ was calculated using FSTAT 2.9.3 (Goudet 2001). Inbreeding coefficient $\left(F_{I S}\right)$ for each population was calculated using Bayesian approach implemented in INEst $\mathrm{v}$. 2.0 , which is robust to the presence of null alleles. The estimation was conducted with 500,000 MCMC cycles with every 200th updated and burn-in of 50,000. Using deviance information criterion, we compared full model with random mating model (when $F_{I S}=0$ ) in order to assess the statistical significance of inbreeding.
Global genetic differentiation among populations was assessed using Wright's fixation index $\left(F_{S T}\right)$ (Weir and Cockerham 1984) with FSTAT v. 2.9.3 (Goudet 2001). Genetic differentiation, as indicated by $F_{S T}$, was re-estimated using null allele correction implemented in FreeNA that eliminates the effect of the null alleles (Chapuis and Estoup 2007). Additionally, the allele size randomization test (Hardy et al. 2003) was performed using SPAGeDI 1.2 (Hardy and Vekemans 2002) to examine whether or not genetic mutation contributes to differentiation among populations. An analysis of the differentiation between populations was conducted based on a comparison of overall $R_{S T}$ to $R_{S T}$ after 10,000 random permutations of allele sizes within a locus. The $R_{S T}$ parameter assumes diversity resulting from mutations according to the stepwise mutation model that is assumed to be dominating in microsatellite markers.

The Beaumont method (Beaumont 1999) in MSVAR 0.4.2 was used to investigate the demographic history of each of the populations to infer a possible bottleneck effect. The model used in MSVAR 0.4.2 assumes that the demographic history of a single population of size $N_{1}$ consist of coalescence and mutations events going back from time $T_{a}$ (in generations) to the current time, until the most recent common ancestor, $N_{0}$. The method allows estimating a set of demographic parameters, $r=N_{0} / N_{1}, t_{f}=t_{a} / N_{0}$ and $\theta=2 N_{0} \mu\left(N_{0}\right.$, current effective population size, $N_{1}$, the ancestral effective population size preceding the demographic change, $\mu$, mutation rate) (Girod 
et al. 2011). The MCMC was run with $10^{9}$ steps, thinning at $3 \times 10^{4}$, and excluding the first $10 \%$ of the steps to avoid a dependence of the final results on starting settings.

The sibship assignment method in Colony 2 software was used to estimate the effective population size $\left(N_{e}\right)$ of each population (Jones and Wang 2010). Sibship assignment method relies on the estimations of most likely full-sibs, half-sibs, and unrelated individuals in a cohort of individuals derived from the sampled population. The main advantage of this software is that it accounts for genotypic errors and allelic dropouts. The fulllikelihood-based analysis (medium likelihood precision and medium length of run) was done under the assumption of polygamy, monoecy, and inbreeding. Locus-specific estimates of null allele frequencies were used as the surrogates for allelic dropout rates, together with genotyping errors provided by INEST 1.0. software (Chybicki and Burczyk 2009).

Genetic clustering analysis was conducted based on Bayesian algorithms implemented in GENELAND v. 3.2.4 software to investigate geographical structure in species genetic diversity distribution (Guillot et al. 2008). This method provides the number of $K$-clusters of genetic homogeneity populations based on genetic structure with optimal H-W and linkage equilibrium. The Spatial and Allele Uncorrelated options with the Null Allele model were initially used in the estimation procedure including georeferenced data. One hundred independent runs with 100,000 iterations each and saving every 100th update with $\mathrm{K}$ set from 1 to 8 were used. The significance of the genetic diversity and differentiation between clusters identified by GENELAND and subspecies were tested with an analysis of molecular variance (AMOVA) as implemented in ARLEQUIN 3.11 (Excoffier et al. 2005). Additionally, the significance of differences in the values of diversity estimators between groups of populations defined with GENELAND and subspecies was tested with 3,000 permutations in FSTAT. GENELAND software was run with a fixed number of clusters in the initial analysis to infer the genetic admixture among populations. The genetic relationships among populations were also analyzed using principle coordinate analysis (PCoA) performed on Nei's genetic distances using GenAlEx v. 6 software (Peakall and Smouse 2006).

Finally, the Mantel test (Mantel 1967) was performed to assess the correlation between geographic and genetic distance (isolation-by-distance (IBD; Rousset 1997) measured as $F_{S T} /\left(1-F_{S T}\right)$ using PopTools v. $3.2(\operatorname{Hood} 2010)$. The significance of the correlation was tested with 1,000 random permutations.

Genetic diversity parameters $\left(H_{E}, A\right.$, and $\left.F_{I S}\right)$ were also correlated with the following environmental factors: altitude, latitude, and longitude data. Linear regression analysis in JMP software (SAS Institute) was used to investigate the geographic trends of genetic diversity in the spatial distribution of Cilician fir taxa. 


\section{Results}

Genetic diversity

Six nSSR markers (SF_b5, SF_333, SF_1, SF_239, SF_78, and SF_b4) provided repeatable and high-quality amplification products and were used to analyze the genetic diversity of the populations. All six of the nSSR loci that were used were polymorphic, with the number of total alleles $(A)$ per locus ranging from 6 (SF_1) to 33 (SF_78). A total of 83 different alleles were identified among the 192 individuals studied. Genetic variation was moderate with the average expected heterozygosity $H_{E}=0.690$ and $A=6.571$ alleles per locus. The highest diversity was reported for locus SF $78\left(H_{E}=\right.$ $0.805)$ and the lowest for locus SF_b5 $\left(H_{E}=0.552\right)$. Null alleles were detected in all loci, and their frequency ranged from 0.15 in SF_b5 to 0.04 in SF_239 with average of 0.098 . Significant departure from HWE was noted in all loci except SF_239 that was probably caused by the null alleles. The highest population differentiation with ENA correction was estimated for locus SF_b5 $\left(F_{S T}=0.264\right)$ and the lowest for SF_b4 $\left(F_{S T}=0.066\right)$.

The average number of alleles per locus $(A)$ in the analyzed populations ranged from 4.5 in LB_2 to 9.5 in TR_1 (Table 1). Allelic richness $(A R)$ was highest in TR_1 (5.8) and lowest in LB_1 (3.9). Observed heterozygosity $\left(H_{O}\right)$ ranged from 0.533 in TR_4 to 0.623 in TR_5, and expected heterozygosity $\left(H_{E}\right)$ ranged from 0.632 in LB_1 to 0.724 in TR_2. Null alleles $\left(N_{0}\right)$ were detected in all populations, with an average of $10.5 \%$ (Table 1). High values for inbreeding coefficient $\left(F_{I S}\right)$ and statistically significant deviations from HWE (at $p=$ 0.05 ) were observed in all studied populations, except TR_1. In $T R \_1$ population in which value of the inbreeding coefficient was lowest, null alleles were probably responsible for deviation from HWE. Neither allelic richness nor expected heterozygosity appeared to be significantly different in both subspecies $\left(H_{E}, p=0.855\right.$; $\left.A_{R}, p=0.854\right)$, i.e., $A$. cilicica subsp. cilicica $\left(H_{E}=0.691\right.$; $\left.A_{R}=4.783\right)$ and $A$. cilicica subsp. isaurica $\left(H_{E}=0.699\right.$; $\left.A_{R}=4.700\right)$.

The estimations of effective population size ranged from 17 (LB_2, TR_10) to 40 (TR_9). MSVAR results indicated that all populations of $A$. cilicica have experienced a strong genetic bottleneck (Table 2). This indicates that, in all cases, the ancestral effective population sizes $\left(N_{l}\right)$ were larger than at present. The geographic pattern of genetic diversity of the analyzed populations, measured as $A R, H$, and $F_{I S}$, revealed a significant latitudinal cline in each of the parameters $\left(r^{2}=\right.$ $0.805, p=0.006, r^{2}=0.764, p=0.010$, and $r^{2}=0.692, p=0.020$, respectively; Supplementary Fig. 1). The regressions between genetic diversity, longitude, and altitude were not significant (data not shown).
Table 2 The estimates of demographic history of A. cilicica populations (populations acronyms as in Table 1)

\begin{tabular}{llll}
\hline Population & Mean $\log (r)$ & $N_{e}$ & $N_{1}$ \\
\hline TR_8 & -0.902 & 33 & 264 \\
TR_9 & -2.308 & 40 & 8,000 \\
TR_10 & -2.867 & 17 & 17,000 \\
TR_11 & -2.009 & 25 & 2,500 \\
TR_12 & -2.894 & 23 & 23,000 \\
LB_1 & -2.512 & 22 & 7,333 \\
LB_2 & -2.402 & 17 & 4,250 \\
\hline
\end{tabular}

$N_{e}$ effective population size, $N_{1}$ ancestral effective population size

Genetic differentiation and geographic patterns

A moderate level of significant genetic differentiation $\left(F_{S T}=\right.$ $0.134, p<0.001$ ) was obtained among compared populations. The statistically significant $(p<0.05)$ population pairwise $F_{S T}$ values ranged from 0.036 between populations TR_ 4 and TR_5 to 0.257 between populations LB_1 and TR_4 (Table 3). Utilizing an ENA correction, the overall genetic differentiation and pairwise $F_{S T}$ were only slightly lower $\left(F_{S T}=0.126\right)$, indicating that null alleles only had a small effect on genetic differentiation (Table 3 ). The total $F_{S T}$ among populations of $A$. cilicica from West Taurus morphologically representing $A$. cilicica subsp. isaurica was lower (0.089) compare with $A$. cilicica from Lebanon Mountains and East Taurus representing $A$. cilicica subsp. cilicica (0.181), but the there was no statistically significant difference in differentiation $(p=0.246)$. The permutation procedure did not confirm any influence of mutations on the pattern of population differentiation as the difference between $R_{S T}\left(0.273\right.$,) and $R_{S T}$ (permuted) $(0.169$; CI, 0.043-0.359) was not significant ( $p=$ $0.167)$. Therefore, the differentiation among populations was not due to stepwise mutation process, and no phylogeographic pattern was detected most likely to have been drift-induced.

A Bayesian analysis of population structure revealed the existence of three clusters $(K=3$ clusters $)$ with a high

Table 3 Matrix of pairwise estimates of $F_{S T}$ with ENA correction below the diagonal and $F_{S T}$ values without correction $(p<0.05)$ above the diagonal among studied populations (population acronyms as in Table 1)

\begin{tabular}{lccccccc}
\hline Population & TR_1 & TR_2 & TR_3 & TR_4 & TR_5 & LB_1 & LB_2 \\
\hline TR_1 & & 0.021 & 0.113 & 0.095 & 0.056 & 0.197 & 0.151 \\
TR_2 & 0.019 & & 0.125 & 0.117 & 0.081 & 0.174 & 0.155 \\
TR_3 & 0.102 & 0.109 & & 0.071 & 0.067 & 0.200 & 0.164 \\
TR_4 & 0.087 & 0.109 & 0.074 & & 0.036 & 0.257 & 0.201 \\
TR_5 & 0.051 & 0.078 & 0.067 & 0.035 & & 0.248 & 0.182 \\
LB_1 & 0.187 & 0.167 & 0.209 & 0.254 & 0.241 & & 0.066 \\
LB_2 & 0.132 & 0.133 & 0.148 & 0.188 & 0.168 & 0.069 & \\
\hline
\end{tabular}


probability of membership to one of the three defined groups (Fig. 1). The cluster analysis revealed geographic structure of the range but did not reflect taxonomic division. Two populations of Cilician fir from Lebanon Mountains, LB_1 and LB_2, were placed in cluster 3 with $99 \%$ of genes, on average, belonging to this cluster. Three populations from the West Taurus (TR_3, TR_4, and TR_5) were put into cluster 2 with $97 \%$ of genes, on average, belonging to this cluster while populations from East Taurus (TR_1 and TR_2) were placed in cluster 1, with $97 \%$ of genes, on average, belonging to this cluster. These results were largely confirmed by ordination of all populations using PCoA analysis. In this analysis, populations were divided into three distinct groups by the first two principle coordinates which explained 61.73 and $21.47 \%$ of the total variation, respectively. Based upon the first coordinate, all Lebanese populations were separated from the other samples (Fig. 2).

Genetic variation among the three clusters defined by GENELAND were statistically significant based on AMOVA ( $11.47 \%$ of the total variance, $p<0.01)$. Moderate, but not significant, differences $(6.28 \%, p=0.057)$ were noted at the subspecies level. The highest level of genetic variation was found within population components of variance (Table 4). The Mantel test indicated significant evidence for IBD among populations with a positive correlation $\left(r^{2}=0.575\right.$, $p=0.004$ ) between genetic and geographic distances. These results underscore the important role of spatial isolation in determining the genetic relationships that exist between populations.

\section{Discussion}

Genetic diversity

This study is one of the first attempts to describe diversity and differentiation of endangered East Mediterranean A. cilicica within the species' natural range and thus importantly supplements a recent study by Awad et al. (2014), which was a regional analysis focused on remnant populations of A. cilicica occurring in Lebanon. Results of our investigations provide information regarding the influence of the structure of the geographic range of the species on the genetic composition of the species which may have practical importance. An additional objective of this study was to identify possible genetic discontinuity between the two subspecies recognized within Cilician fir that might have significant taxonomic implications important from a conservation perspective as well.

The nSSR data indicated that all of the examined populations of $A$. cilicica tend to maintain a relatively high level of genetic diversity for a species with limited range and very disjunct occurrence. Our results thus correspond to previous studies obtained for Cilician fir from Turkey and Syria (Scaltsoyiannes et al. 1999; Liepelt et al. 2010). It is generally expected to find low genetic variability in species with restricted distribution pattern, especially in endemic or rare species. A low level of genetic diversity was recently reported in the West Mediterranean Abies pinsapo and Abies marocana, which likewise have very limited distribution and low-density populations (Dering et al. 2014). However, a particular set of life-history traits that are found in tree species enable them to keep high within-population genetic diversity (Petit and Hampe 2006). High genetic diversity was observed in other coniferous species from the East Mediterranean (Dagher-Kharrat et al. 2007; Douaihy et al. 2011; Sobierajska 2012) and from the Mediterranean in general (Terrab et al. 2007; Boratyński et al. 2009; Liepelt et al. 2010; Dzialuk et al. 2011; Boratyński et al. 2014). Higher levels of genetic variability observed in East Mediterranean species compared with West Mediterranean species is believed to be related to the relatively more stable palaeoenvironmental conditions prevailing in the eastern part of the region during the last glacial cycle (Fady and Conord 2010).

The increasing of $A R, H_{E}$, and $F_{I S}$ (Supplementary Fig. 1) with latitude, noted in our study reflects the lower genetic diversity noted in the Lebanese populations compared with
Fig. 2 Principal coordinates analysis (PCoA) based on first two axes (populations acronyms as in Table 1)

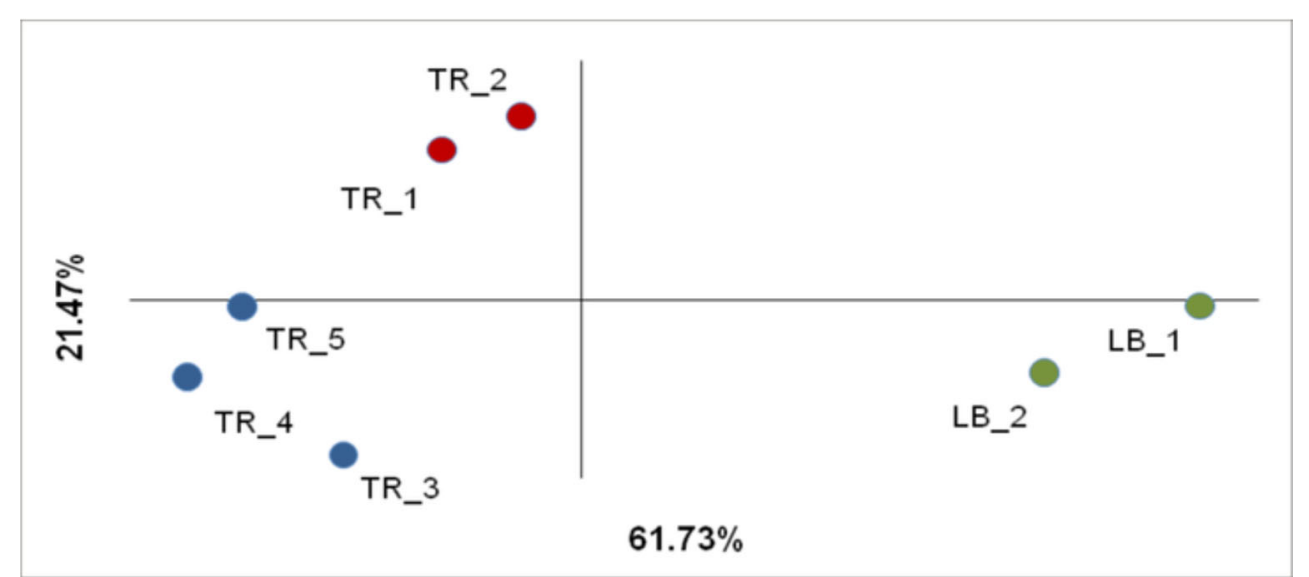


Table 4 Analysis of molecular variance (AMOVA) for six nSSR markers

\begin{tabular}{|c|c|c|c|c|c|}
\hline Source of variation & & df & Sum of squares & Variance components & $\%$ variation \\
\hline \multirow[t]{3}{*}{ GENELAND clusters } & Among groups & 2 & 83.77 & 0.28 & $11.47 * *$ \\
\hline & Among population within groups & 4 & 31.12 & 0.11 & $4.43 * * *$ \\
\hline & Within populations & 377 & 767.68 & 2.04 & $84.10 * * *$ \\
\hline \multirow[t]{3}{*}{ Among subspecies } & Among subspecies & 1 & 44.12 & 0.15 & 6.28 \\
\hline & Among population within subspecies & 5 & 70.77 & 0.23 & $9.36^{* * *}$ \\
\hline & Within populations & 377 & 767.68 & 2.04 & $84.36 * * *$ \\
\hline
\end{tabular}

$* * * p<0.001,{ }^{* *} p<0.01,{ }^{*} p<0.05$ levels of significance

the Turkish stands, which agrees with the results obtained recently by Awad et al. (2014). According to those authors, fragmentation has negatively affected the level of genetic diversity in populations of Cilician fir from Lebanon. Similar to other fir species, Cilician fir was distributed more widely in the past, and the main factor responsible for the fragmentation of the previously continuous range can be most likely attributed to the hyper-aridity of the climate during periods of the Pleistocene (Linares 2011). Additionally, in the Younger Dryas (Orland et al. 2012), as well as in the Holocene, abrupt episodes of dryness were noted in the East Mediterranean, which resulted in the development of an open, tree-less landscape as indicated by pollen records from the Bekaa Valley in Lebanon (Hajar et al. 2008). The decline of populations in Lebanon can also be attributed to human activity that has been noted in this region, since the early Holocene (Hajar et al. 2008). Large deforestations in Lebanon began in ancient times when Lebanese forests supplied timber to Egypt (Talhouk et al. 2001). More recently, Cilician fir forests became highly fragmented in Lebanon due to the logging that occurred during World Wars I and II and the expansion of agricultural activity, both of which have resulted in the degradation of the populations of most tree species in that region (Talhouk et al. 2001; Fady et al. 2008; Douaihy et al. 2011; Awad et al. 2014).

A bottleneck effect that has been detected, current low population size, and fragmentation all may have a negative effect on Cilician fir stands due to their impact on the intensification of drift and inbreeding. Recently, Poudel et al. (2014) have reported increased level of inbreeding in populations of three Asiatic yew species pointing to a causative role of population fragmentation. According to our results, inbreeding might be the current issue for Cilician fir populations. In all populations except one (TR_1), the departure from Hardy-Weinberg equilibrium resulting in an excess of homozygotes was noted. In addition, our estimates of $N_{e}$ are far below the recommended general values $(500-1,000)$ for longterm conservation when considering mutation, drift, and selection (Franklin and Frankham 1998). Low effective population sizes expose the remnant population of Cilician fir to genetic drift, which generally causes a population to be more inbred even if mating stays random. In small populations, drift may dominate the force of natural selection and may lead to a loss of adaptive genetic variation and fixation of deleterious alleles (Whitlock 2000). It seems that, due to rage fragmentation, genetic drift has become a leading evolutionary force acting in populations of Cilician fir. In the context of predicted climate and environmental changes, such a situation could have a serious, negative impact on the adaptive potential of the species.

\section{Pattern of differentiation}

A moderate level of genetic differentiation $\left(F_{S T}=0.134\right.$; $p<0.001)$ was noted among the examined fir populations and has been reported for other Mediterranean tree species (Petit et al. 2005). Fady-Welterlen (2005) reported that genetic differentiation among populations of Mediterranean species reaches $10-13 \%$. Such a geographical pattern of genetic interpopulation differentiation has evolved in response to frequently and abruptly changing climatic conditions and the geological complexity within the Mediterranean region during the last glacial cycle since ca. $100 \mathrm{ka} \mathrm{BP}$ (Van Andel and Tzedakis 1996) or, more probably, during the whole Quaternary period spanning the past 1.6 million years (Thompson 2005).

Awad et al. (2014) has recently reported very low values of genetic differentiation among the Lebanese population of Cilician fir as $F_{S T}=0.0536$ and $R_{S T}=0.0374$. The significant differentiation we have detected among populations of A. cilicica from the Lebanon mountains versus East Taurus and from the Lebanon mountains versus West Taurus likely reflects the long period of genetic isolation which has probably been induced by range fragmentation related to Pleistocene climatic alternations. The general effect of an increase in atmospheric aridity, brought about by the cold conditions of the last glaciation (Elenga et al. 2000; FadyWelterlen 2005) on mountain species in the Mediterranean region, was an altitudinal migration (Fady et al. 2008; Fady and Conord 2010) that likely severely hindered gene exchange between refugial populations and promoted genetic divergence, especially in small populations. A similar geographically driven pattern of genetic differentiation has also 
been observed in J. excelsa M.-Bieb. (Dagher-Kharrat et al. 2007), C. libani A. Rich. (Dagher-Kharrat et al. 2007; Fady et al. 2008), and J. drupacea Labill. (Sobierajska 2012) in the East Mediterranean.

The significant IBD pattern detected among populations of A. cilicica also confirms that the spatial isolation among populations from West Taurus, East Taurus, and the Lebanon mountains was one of the major evolutionary mechanisms leading to the within-species differentiation. Minor genetic admixture was found among populations from Lebanon and East Taurus and among populations from West Taurus and East Taurus, while no genetic admixture was detected for populations from West Taurus and the Lebanon mountains. These findings may indicate either that (1) there is no gene exchange among currently isolated populations and minor admixture is a genetic echo of the past, or (2) recurrent gene flow is very limited. Either of these hypotheses is possible, but none can be fully verified with the current data. With respect to Cilician fir populations from Lebanon, Awad et al. (2014) reported intensive gene exchange. However, in the scale of the whole species range, it might not be the case, and physical isolation among different mountain ranges acts as an effective biogeographical barrier. In a broader context, our findings of geographically driven spatial distribution of genetic variation in Cilician fir is supported by other biogeographical studies recognizing the prominent function of mountain systems in the spatial organization of diversity and differentiation of a species with mountainous occurrence. Mountain ranges are among the basic elements that have played a crucial role in the evolution of the uniqueness and species richness of the Mediterranean flora (Thompson 2005). Similarly, vicariant gene pools in major European mountain chains have been noted, and frequently observed phylogeographic breaks include the Alpine-Carpathian (Höhn et al. 2009) and Western-Eastern Carpathian division (StachurskaSwakon et al. 2013).

From a conservation perspective, our results supply important knowledge. Species range fragmentation that started in Pleistocene has probably initiated the differentiation of Cilician fir populations. Modern deforestations by reducing population size increased fragmentation and brought about unfavorable effects such as inbreeding. Even if, currently, genetic diversity in populations maintains on a relatively high level, there is reasonable threat of loss of genetic variability in the longer perspective, especially if genetic drift will be a dominant evolutionary force. In comparison to herbaceous species, woody tree species seemed to be resistant to fragmentation-dependent genetic pauperization due to a very particular set of life-history traits; however, the latest study by Vranckx et al. (2012) proves susceptibility of trees to fragmentation as well. The need for conservation measures aimed at the preservation of Cilician fir genetic resources representing the Tertiary heritage of the Mediterranean flora is highly relevant and urgent, especially with respect to the Lebanese stands of $A$. cilicica. Our results indicate that there is a need to develop an effective program designed to protect and maintain the remnant genetic resources of Cilician fir growing in Turkey as well. Due to the economic value of Cilician fir in Turkey, stands of this species are managed. Therefore, future efforts should focus on monitoring the demography and genetic threats to existing populations in order to avoid overexploitation and/or further loss of genetic diversity.

In reference to taxonomic issues, our analysis failed to detect significant genetic differentiation between the subspecies of Cilician fir that are recognized based on morphology (Farjon 2010). However, our results are not final, mainly because nSSR-based genetic patterns do not have to follow taxonomic entities. There are some studies in which these kinds of markers helped to resolve taxonomic doubts or give some new insights (Boratyński et al. 2014; Dering et al. 2014), but generally reliable phylogenetic analysis requires the use of more appropriate markers and statistical tools.

Acknowledgments This research was funded by the National Science Centre (NCN) of Poland (number N N303 412136) and the Institute of Dendrology Polish Academy of Science. We thank A.K. Jasińska, M. Ratajczak, and M. Łuczak for technical support.

Data Archiving Statement Linear regression analysis between nSSR's - expected heterozygosity (HE), allelic richness (AR), and inbreeding coefficient (FIS) of A. cilicica populations versus latitude and altitude data (Supplementary Fig. 1)

SSR genotype data used in this study are available as supplemental text files (Supplementary Table 1).

Open Access This article is distributed under the terms of the Creative Commons Attribution License which permits any use, distribution, and reproduction in any medium, provided the original author(s) and the source are credited.

\section{References}

Abbott RJ, Ritchie MG, Hollingsworth PM (2008) Introduction. Speciation in plants and animals: pattern and process. Philos Trans R Soc Lond B Biol Sci 363:2965-2969. doi:10.1098/rstb.2008.0096

Aguilée R, Claessen D, Lambert A (2013) Adaptive radiation driven by the interplay of eco-evolutionary and landscape dynamics. Evolution 67:1291-1306. doi:10.1111/evo.12008

Akkemiik Ü (2000) Tree-ring chronology of Abies cilicica Carr. in the Western Mediterranean region of Turkey and its response to climate. Dendrochronologia 18:73-81

Aussenac G (2002) Ecology and ecophysiology of circum-Mediterranean firs in the context of climate change. Ann For Sci 59:10. doi:10. 1051/forest: 2002080

Awad L, Fady B, Khater C et al (2014) Genetic structure and diversity of the endangered fir tree of Lebanon (Abies cilicica Carr.): implications for conservation. PLoS ONE 9:e90086. doi:10.1371/journal.pone.0090086 
Beaumont MA (1999) Detecting population expansion and decline using microsatellites. Genetics 153:2013-2029

Boratyński A, Lewandowski A, Boratyńska K et al (2009) High level of genetic differentiation of Juniperus phoenicea (Cupressaceae) in the Mediterranean region: geographic implications. Plant Syst Evol 277:163-172. doi:10.1007/s00606-008-0122-z

Boratyński A, Wachowiak W, Dering M et al (2014) The biogeography and genetic relationships of Juniperus oxycedrus and related taxa from the Mediterranean and Macaronesian regions. Bot J Linn Soc 174:637-653. doi:10.1111/boj.12147

Browicz K, Zieliński J (1984) Chorology of trees and shrubs in southwest Asia and adjacent regions. PWN, Warszawa

Chapuis M-P, Estoup A (2007) Microsatellite null alleles and estimation of population differentiation. Mol Biol Evol 24:621-631. doi:10. 1093/molbev/ms1191

Chybicki IJ, Burczyk J (2009) Simultaneous estimation of null alleles and inbreeding coefficients. J Hered 100:106-113. doi:10.1093/jhered/ esn088

Collins PM, Davis BAS, Kaplan JO (2012) The mid-Holocene vegetation of the Mediterranean region and southern Europe, and comparison with the present day. J Biogeogr 39:1848-1861. doi:10.1111/j.13652699.2012.02738.x

Comes HP, Tribsch A, Bittkau C (2008) Plant speciation in continental island floras as exemplified by Nigella in the Aegean Archipelago. Philos Trans R Soc Lond B Biol Sci 363:3083-3096. doi:10.1098/ rstb.2008.0063

Coode MJE, Cullen J (1965) Abies Miller. In: Davis PH (ed) Flora of Turkey 1. Edinburgh University Press, Edinburgh, pp 67-70

Cremer E, Liepelt S, Sebastiani F et al (2006) Identification and characterization of nuclear microsatellite loci in Abies alba Mill. Mol Ecol Notes 6:374-376. doi:10.1111/j.1471-8286.2005.01238.x

Dagher-Kharrat M, Mariette S, Lefèvre F et al (2007) Geographical diversity and genetic relationships among Cedrus species estimated by AFLP. Tree Genet Genome 3:275-285. doi:10.1007/s11295006-0065-x

Dering M, Katarzyna S, Krystyna B et al (2014) Genetic diversity and inter-specific relations of western Mediterranean relic Abies taxa as compared to the Iberian A. alba. Flora Morphol Distrib Funct Ecol Plants. doi:10.1016/j.flora.2014.03.011

Douaihy B, Vendramin GG, Boratynski A et al (2011) High genetic diversity with moderate differentiation in Juniperus excelsa from Lebanon and the eastern Mediterranean region. AoB Plants 2011: plr003. doi:10.1093/aobpla/plr003

Dumolin S, Demesure B, Petit RJ (1995) Inheritance of chloroplast and mitochondrial genomes in pedunculate oak investigated with an efficient PCR method. Theor Appl Genet 91:1253-1256

Dzialuk A, Mazur M, Boratyńska K et al (2011) Population genetic structure of Juniperus phoenicea (Cupressaceae) in the western Mediterranean basin: gradient of diversity on a broad geographical scale. Ann For Sci 68:1341-1350. doi:10.1007/s13595-011-0150-7

Elenga H, Peyron O, Bonnefille R et al (2000) Pollen-based biome reconstruction for southern Europe and Africa 18,000 yr BP. J Biogeogr 27:621-634. doi:10.1046/j.1365-2699.2000.00430.x

Excoffier L, Laval G, Schneider S (2005) Arlequin (version 3.0): an integrated software package for population genetics data analysis. Evol Bioinform 1:47-50

Fady B, Conord C (2010) Macroecological patterns of species and genetic diversity in vascular plants of the Mediterranean basin. Divers Distrib 16:53-64. doi:10.1111/j.1472-4642.2009.00621.x

Fady B, Lefèvre F, Vendramin GG et al (2008) Genetic consequences of past climate and human impact on eastern Mediterranean Cedrus libani forests. Implications for their conservation. Conserv Genet 9: 85-95. doi:10.1007/s10592-007-9310-6

Fady-Welterlen B (2005) Is there really more biodiversity in Mediterranean forest ecosystems? Taxon 54:905-910

Farjon A (2010) A handbook of the world's conifers. Brill, Leiden
Franklin IR, Frankham R (1998) How large must populations be to retain evolutionary potential? Anim Conserv 1:69-70. doi:10.1111/j.14691795.1998.tb00228.x

Gardner M, Knees S (2013) Abies cilicica. The IUCN red list of threatened species. Version 2014.2. www.iucnredlist.org

Geburek T, Hiess K, Litschauer R, Milasowszky N (2012) Temporal pollen pattern in temperate trees: expedience or fate? Oikos 121: 1603-1612. doi:10.1111/j.1600-0706.2011.20140.x

Girod C, Vitalis R, Leblois R, Fréville H (2011) Inferring population decline and expansion from microsatellite data: a simulation-based evaluation of the Msvar method. Genetics 188:165-179. doi:10. 1534/genetics.110.121764

Goudet J (2001) FSTAT, a program to estimate and test gene diversities and fixation indices (version 2.9.3). Updated from Goudet (1995)

Grivet D, Robledo-Arnuncio JJ, Smouse PE, Sork VL (2009) Relative contribution of contemporary pollen and seed dispersal to the effective parental size of seedling population of California valley oak (Quercus lobata, Née). Mol Ecol 18:3967-3979. doi:10.1111/j. 1365-294X.2009.04326.x

Guillot G, Santos F, Estoup A (2008) Analysing georeferenced population genetics data with Geneland: a new algorithm to deal with null alleles and a friendly graphical user interface. Bioinformatics 24 : 1406-1407. doi:10.1093/bioinformatics/btn136

Hajar L, Khater C, Cheddadi R (2008) Vegetation changes during the late Pleistocene and Holocene in Lebanon: a pollen record from the Bekaa Valley. The Holocene 18:1089-1099. doi:10.1177/ 0959683608095580

Hardy OJ, Vekemans X (2002) spagedi: a versatile computer program to analyse spatial genetic structure at the individual or population levels. Mol Ecol Notes 2:618-620. doi:10.1046/j.1471-8286.2002. 00305.x

Hardy OJ, Charbonnel N, Fréville H, Heuertz M (2003) Microsatellite allele sizes: a simple test to assess their significance on genetic differentiation. Genetics 163:1467-1482

Höhn M, Gugerli F, Abran P et al (2009) Variation in the chloroplast DNA of Swiss stone pine (Pinus cembra L.) reflects contrasting post-glacial history of populations from the Carpathians and the Alps. J Biogeogr 36:1798-1806. doi:10.1111/j.1365-2699.2009. 02122.x

Hood GM (2010) PopTools version 3.2.5. Available on the Internet. URL http://www.poptools.org

Hopkins R (2013) Reinforcement in plants. New Phytol 197:1095-1103. doi:10.1111/nph.12119

Jalas J, Suominen J (1988) Atlas Florae Europaeae: distribution of vascular plants in Europe. The Committee for Mapping the Flora of Europe and Societas Biologica Fennica. Vanamo, Helsinki

Jones OR, Wang J (2010) COLONY: a program for parentage and sibship inference from multilocus genotype data. Mol Ecol Resour 10:551555. doi:10.1111/j.1755-0998.2009.02787.x

Kavgaci A, Basaran S, Basaran MA (2010) Cedar forest communities in Western Antalya (Taurus Mountains, Turkey). Plant Biosyst 144: 271-287. doi:10.1080/11263501003690720

Kaya Z, Raynal DJ (2001) Biodiversity and conservation of Turkish forests. Biol Conserv 97:131-141. doi:10.1016/S0006-3207(00) 00069-0

Leroy SAG, Arpe K (2007) Glacial refugia for summer-green trees in Europe and south-west Asia as proposed by ECHAM3 time-slice atmospheric model simulations. J Biogeogr 34:2115-2128. doi:10. 1111/j.1365-2699.2007.01754.x

Liepelt S, Mayland-Quellhorst E, Lahme M, Ziegenhagen B (2010) Contrasting geographical patterns of ancient and modern genetic lineages in Mediterranean Abies species. Plant Syst Evol 284:141151. doi:10.1007/s00606-009-0247-8

Linares JC (2011) Biogeography and evolution of Abies (Pinaceae) in the Mediterranean basin: the roles of long-term climatic change and 
glacial refugia. J Biogeogr 38:619-630. doi:10.1111/j.1365-2699. 2010.02458.x

Mantel N (1967) The detection of disease clustering and a generalized regression approach. Cancer Res 27:209-220

Mayr E (1964) Systematics and the origin of species from the viewpoint of a zoologist: with a new introduction by the Author. Dover

Muller SD, Nakagawa T, De Beaulieu J-L et al (2007) Post-glacial migration of silver fir (Abies alba Mill.) in the south-western Alps. J Biogeogr 34:876-899. doi:10.1111/j.1365-2699.2006.01665.x

Orland IJ, Bar-Matthews M, Ayalon A et al (2012) Seasonal resolution of Eastern Mediterranean climate change since $34 \mathrm{ka}$ from a Soreq Cave speleothem. Geochim Cosmochim Acta 89:240-255. doi:10. 1016/j.gca.2012.04.035

Peakall R, Smouse PE (2006) genalex 6: genetic analysis in Excel. Population genetic software for teaching and research. Mol Ecol Notes 6:288-295. doi:10.1111/j.1471-8286.2005.01155.x

Petit RJ, Hampe A (2006) Some evolutionary consequences of being a tree. Annu Rev Ecol Evol Syst 37:187-214. doi:10.1146/annurev. ecolsys.37.091305.110215

Petit RJ, Hampe A, Cheddadi R (2005) Climate changes and tree phylogeography in the Mediterranean. Taxon 54:877-885

Poska A, Pidek IA (2009) Pollen dispersal and deposition characteristics of Abies alba, Fagus sylvatica and Pinus sylvestris, Roztocze region (SE Poland). Veg Hist Archaeobotany 19:91-101. doi:10.1007/ s00334-009-0230-x

Poudel RC, Möller M, Liu J et al (2014) Low genetic diversity and high inbreeding of the endangered yews in Central Himalaya: implications for conservation of their highly fragmented populations. Diversity Distrib n/a-n/a. doi:10.1111/ddi.12237

Roberts N, Reed JM, Leng MJ et al (2001) The tempo of Holocene climatic change in the eastern Mediterranean region: new highresolution crater-lake sediment data from central Turkey. The Holocene 11:721-736. doi:10.1191/09596830195744

Robledo-Arnuncio JJ (2011) Wind pollination over mesoscale distances: an investigation with Scots pine. New Phytol 190:222-233. doi:10. $1111 / j .1469-8137.2010 .03588 . x$

Rousset F (1997) Genetic differentiation and estimation of gene flow from F-statistics under isolation by distance. Genetics 145:1219-1228

Scaltsoyiannes A, Tsaktsira M, Drouzas AD (1999) Allozyme differentiation in the Mediterranean firs (Abies, Pinaceae). A first comparative study with phylogenetic implications. Plant Syst Evol 216:289-307. doi:10.1007/BF01084404

Schluter D (2001) Ecology and the origin of species. Trends Ecol Evol 16:372-380. doi:10.1016/S0169-5347(01)02198-X
Schütt P (1991) Tannenarten Europas und Kleinasiens. Birkhäuser, Basel

Slatkin M (1987) Gene flow and the geographic structure of natural populations. Science 236:787-792. doi:10.1126/ science. 3576198

Slatkin M (1995) A measure of population subdivision based on microsatellite allele frequencies. Genetics 139:457-462

Sobierajska K (2012) Pozycja taksonomiczna i zróżnicowanie geograficzne Juniperus drupacea Labill. (Cupressaceae). PhD thesis. Institute of Dendrology PAS. Kórnik

Stachurska-Swakon A, Cieslak E, Ronikier M (2013) Phylogeography of a subalpine tall-herb Ranunculus platanifolius (Ranunculaceae) reveals two main genetic lineages in the European mountains. Bot J Linn Soc 171:413-428. doi:10.1111/j.1095-8339.2012. 01323.x

Talhouk SN, Zurayk R, Khuri S (2001) Conservation of the coniferous forests of Lebanon: past, present and future prospects. Oryx 35:206215. doi:10.1046/j.1365-3008.2001.00180.x

Talhouk S, Zurayk R, Khuri S (2003) Conifer conservation in Lebanon. In: Mill R (ed) Proceedings of the Fourth International Conifer Conference: conifers for the Future? International Society Horticultural Science, Leuven 1, pp 411-414

Terrab A, Talavera S, Arista M et al (2007) Genetic diversity at chloroplast microsatellites (cpSSRs) and geographic structure in endangered West Mediterranean firs (Abies spp., Pinaceae). Taxon 56: 409-416

Thompson JD (2005) Plant evolution in the Mediterranean. Oxford University Press, New York

Van Andel TH, Tzedakis PC (1996) Palaeolithic landscapes of Europe and environs, 150,000-25,000 years ago: an overview. Quat Sci Rev 15:481-500. doi:10.1016/0277-3791(96)00028-5

Vranckx G, Jacquemyn H, Muys B, Honnay O (2012) Meta-analysis of susceptibility of woody plants to loss of genetic diversity through habitat fragmentation. Conserv Biol 26:228-237. doi:10.1111/j. 1523-1739.2011.01778.x

Weir B, Cockerham C (1984) Estimating F-statistics for the analysis of population structure. Evolution 38:1358-1370

Whitlock MC (2000) Fixation of new alleles and the extinction of small populations: drift load, beneficial alleles, and sexual selection. Evolution 54:1855-1861

Wright S (1931) Evolution in Mendelian populations. Genetics 16:97159

Young A, Boyle T, Brown T (1996) The population genetic consequences of habitat fragmentation for plants. Trends Ecol Evol 11:413-418. doi:10.1016/0169-5347(96)10045-8 